\title{
Farm Household Preferences and Evaluation of Land Use Change Policies for Agro-Forestry Plantations in Central Kalimantan, Indonesia : a Choice Experiment
}

\author{
Sitompul, R*, Brouwer, R*, Sopaheluwakan, $\mathrm{J}^{\#}$, van Beukering, $\mathrm{P}^{*}$ \\ \# International Center for Interdisciplinary and Advanced Research (ICIAR), Indonesian Institute of Sciences (LIPI), Jakarta, Indonesia \\ E-mail: rislima@gmail.com; jan@sopaheluwakan.com \\ * Institute for Environmental Studies, Vrije Universiteit Amsterdam, The Netherlands \\ E-mail:roy.brouwer@vu.nl; pieter.van.beukering@vu.nl
}

\begin{abstract}
A household survey for the analysis of choice experiment were made to 360 farmers in three selected villages in Central Kalimantan Province. The objective is to analyze the current land use and to observe the perception of farmers on converting part of their land use for bioenergy plantation. The Choice Experiment is used to find a combination of appropriate payment systems to replace the use of the existing land for their farming. From the analysis of Choice Experiment can be explained comparison of the two approaches, that is, models without any interaction and models with interaction. On models without significant interaction effect on farmers' preferences is Contract Provider (prov), contract length (c-length), water table, land set-aside, compensation, Age, Age2, and income on the real level of $10 \%$. To obtain more accurate results the researchers include variables of interaction between the characteristics of the respondents with a primary variable in order to obtain the best model from the model. From the results of choice experiments good, both without interaction and with interaction can explain what factors that will influence farmers' decisions in choosing their compensation, as a result of implementing bioenergy development.
\end{abstract}

Keywords — Bioenergy; choice experiment; household survey; interaction variable; Central Kalimantan

\section{INTRODUCTION}

This research is aimed to investigate economic potentials of implementing bioenergy development for carbon sequestration in Central Kalimantan under different scenarios of land use changes, and how land use changes could improve the livelihoods of small holders through carbon emission reduction. In order for the bioenergy projects could enter the formal carbon market, the project should demonstrate that it will reduce emissions or produce biomass carbon additional to a business-as-usual scenario. This means that the bioenergy projects demonstrate 'additionality' in the absence of the current farming activities (concept of additionality). Baselines in this study is assumed current farming activities that was observed from the survey. The level of carbon changes in the proposed project would underlie the selection of attribute in the Choice Experiment analysis. For the purpose of this study, four villages in the Province of Central Kalimantan are selected that represent the type of farmer groups doing farming activities there according to their originality: spontaneous settler, local/Dayak people, and transmigrant.
Bioenergy vegetations were selected based on observation at the field survey at each location of the study area, in addition to land suitability for the corresponding crops. The field survey in each village observed several bioenergy crops that has been practised by farmers. One of them, sagoo, is one of the traditional crops. There are four bioenergy plantation that were considered in this study: Sagoo, nyamplung, jatropha curcas and palm oil.

Land use change is driven by a combination of socioeconomic (e.g. income levels, infrastructure, demographic structure), political (e.g. land tenure, subsidies, nature protection) and biophysical (e.g. soil and climate characteristics) factors, the so-called land use drivers [1]. Therefore, when determining the study area it is necessary to consider the social groups that reside in those areas. Other than social group, the selection was based on the availability of data on agro forestry and bioenergy systems to be adopted by smallholders, the land availability and suitability for selected bioenergy plants including parameters soil, $\mathrm{pH}$ level and depth of peatland. Further considerations were taken into account that are related to current agroforestry practiced and bioeenergy plantations prefered by farmers. It is 
important to note that, farmers from different ethnic/ villages have different land use and farming systems, and therefore, different levels of income from land and different total farm system incomes. Farmers with different ethnic backgrounds also have different interests and capabilities to adopt bioenergy crops. In this case, transmigrants are more adaptive to innovation and new farming practice. Bioenergy crops were selected based on observation at the field survey at each location of the study area, in addition to land suitability for the corresponding plants. The field survey in each village identified several bioenergy crops that has been practised by farmers.

\section{THE SURVEY}

An easy way to comply with the conference paper formatting requirements is to use this document as a template and simply type your text into it.

Household survey for choice experiment analysis was performed to 360 farmers in the selected villages. The objective is to analyze the current land use practices and to observe the farmer's perception on coverting part of their land use into bioenergy development purposes. The main objective is to find the appropriate payment arrangement for the compensation of the new land use over the current agricultural practices.

Therefore, the research questions are: (1) What is the amount of willingness to accept of the farmers to change their land-use; (2) What type of bioenergy trees that they are willing to plant considering the carbon payment they will receive as a result of the land use-changes.

The farmers who will be interviewed consists of three social groups: local (Dayak people), spontaneus settlers, and transmigrant. Most of the farmers own land at minimum of 2 ha. The farmers define the target group as: Farmers who own or rent of peat land ranging at 2-10 ha and currently planted with other agricultural crops. The farmers to be interviewed should be fully engaged in farming activities as the main objective of the research is to investigate the opportunity cost of converting the current crops into bioenergy crops.

Several general indicators will be oserved: (1) Years of arrival : local (Dayak people), spontaneus settlers, and transmigrant; (2) Land Use: number of years of cultivation; (3) Land use pattern by type of soil (shallow peat, deep peat, and mineral soil); (4) Type of current cultivation.

Before conducting the field work (survey), the interviewers were all trained on the purpose and target of the study, the method, the sampling, anticipated questions from the respondents, the code of conducts at interviewing, etc. Each interviewer will be prepared with complete survey document (questionnaieres, supporting illustration, etc) and essentials. There will be appointed one team leader of the interviewer working for each village.

Some key informants will be interviewed, such as local government officials at provinves, district/ kabupaten, subdistrict/kecamatan and village levels, village informal leaders, village representatives as well as local NGO representatives.

\section{A. Sample Selection for the Survey}

The survey is implemented at two sub-districts at Pulang Pisau District: Maliku and Pandih Batu. The respondents should be farmers who own property land, work on peat land and have practiced fire burn for their peatland.Pulang Pisau district located at the peat land Blocks, called Block A, B and $\mathrm{C}$. Block $\mathrm{A}$ is located near the Kahayan River, and Block $\mathrm{B}$ and Block $\mathrm{C}$ are further distance from the river. The further from the river is likely to have deeper peat land. Block $\mathrm{C}$ has relatively deeper peatland compared the other blocks (more than 0.5 meter), which is mostly located at Maliku sub-district.

\section{B. Sample Size and Sampling Plan}

The main objective of the survey is to observe farmers' preferences, the population in this survey is defined as the number of farmers in the District. It is estimated $50 \%$ of the farmers and fishermen population are farmers only. Therefore, the number of population used to estimate the sampling size is $50 \%$ of total population of farmers and fishermen.We will apply random sampling by estimating sample size as shown in Table I.

TABLE I

SAMPLE SIZE AT EACH SUBDISTRICT

\begin{tabular}{|c|c|c|c|c|c|c|}
\hline $\begin{array}{c}\text { Sub } \\
\text { distrcit }\end{array}$ & $\begin{array}{l}\text { Farmer } \\
\text { /fisher } \\
\text { men }\end{array}$ & $\begin{array}{c}\text { Farmer } \\
(50 \%)\end{array}$ & $\begin{array}{l}\text { Sampl } \\
\text { ing } \\
\text { Size } \\
\end{array}$ & $\begin{array}{l}\text { Sampl } \\
\text { ing } \\
\text { Size }^{2)} \\
\end{array}$ & $\begin{array}{c}\text { Sampl } \\
\text { ing } \\
\text { size }^{3)} \\
\end{array}$ & $\begin{array}{c}\text { Real } \\
\text { sampl } \\
\text { ing }\end{array}$ \\
\hline Maliku & 6,671 & 3,336 & 357 & 186 & 144 & 240 \\
\hline $\begin{array}{l}\text { Pandih } \\
\text { Batu }\end{array}$ & 7,554 & 3,777 & 362 & 186 & 144 & 120 \\
\hline & 14,225 & 7,113 & 719 & 372 & 288 & 360 \\
\hline 1) & \multicolumn{6}{|c|}{$\begin{array}{l}\text { Simple random sampling formula: } \\
\text { Stovin Equation } \\
\mathrm{n}=\mathrm{N} / \mathrm{N}(\mathrm{d})^{2}+1 \\
\mathrm{n}=\text { sample size; } \mathrm{N}=\text { population } \mathrm{d}=\text { confidence level } 95 \%\end{array}$} \\
\hline 2) & \multicolumn{6}{|c|}{$\begin{array}{l}\text { use sampling size calculator } \\
\text { http://www.surveysystem.com/sscalc.htm, with confidence } \\
\text { interval : } 7 \text {, confidence level: } 95 \%\end{array}$} \\
\hline 3) & \multicolumn{6}{|c|}{$\begin{array}{l}\text { use sampling size calculator } \\
\text { http://www.surveysystem.com/sscalc.htm, with confidence } \\
\text { interval : } 8 \text {, confidence level: } 95 \%\end{array}$} \\
\hline
\end{tabular}

There were six interviewers involved. During the pretest, each of them interviewed 2-3 respondents. At the real survey, there were 360 respondents who have successfully interviewed, with the following interviewers and location of survey as shown in Table II. The survey were implemented in 3 villages, i.e., Gandang Barat, Kantan Atas, and Sidodadi.

TABLE II

INTERVIEWER AND THE SURVEY LOCATION

\begin{tabular}{|l|l|l|l|c|}
\hline No & Interviewer & Village & District & $\begin{array}{c}\text { Number of } \\
\text { respondents } \\
\text { interviewed }\end{array}$ \\
\hline 1 & Kasmat & GandangBarat & Maliku & 36 \\
\hline 2 & Ngadiran & Kantan Atas & Pandih Batu & 36 \\
\hline 3 & Srianto & Gandang Barat & Maliku & 36 \\
\hline 4 & Sukri & Sidodadi & Maliku & 36 \\
\hline 5 & $\begin{array}{l}\text { Khotibul } \\
\text { Umam }\end{array}$ & Kantan atas & Pandih batu & 36 \\
\hline 6 & Ali Usni & Sidodadi & Maliku & 36 \\
\hline 7 & Purwati & Gandang Barat & Maliku & 36 \\
\hline 8 & Sunarto & Kantan atas & Pandih batu & 36 \\
\hline 9 & Kamdani & Kantan atas & Pandih batu & 36 \\
\hline 10 & Supriatin & Sidodadi & Maliku & 36 \\
\hline
\end{tabular}




\section{THE METHODOLOGY}

\section{A. Choice Experiment}

In a choice experiment, individuals are asked to choose their preferred alternative from several options in a choice set, and they are usually asked to respond to a sequence of such choices. Choice experiments are arguably the simplest of the choice-based approaches in terms of cognitive requirements from respondents. Also, choice experiments mirror real market situations and are consistent with welfare economics [2].

Choice Expxeriment explains the diversity of behavioral responses of individuals in a population sample [3]. This method is often used in discrete choice problems. Preparation of the choice model is the most important issue in a choice experiment. Failure in building the model choice could result in difficulties in finding solutions to the defined problems as as expected. Therefore, in modeling the alternative available options, the researcher should be able to define what factors that are considered in making decision related to the existing alternatives or attribute. However, one's choice decision can be influenced by sociodemographic circumstances of the person, such as gender, age, and family size.

Choice Modelling has a number of advantages in minimising framing effects. The most significant it allows the simultaneous presentation of a pool of other goods [4]. As a result, respondents are automatically required to consider complementary and substitution effects in the choice process. This also reduces potential problems of bias because the amenity of interest can be 'hidden' within the pool of available goods used in a Choice Model experiment.

In this study, we consider the farmers preference for a land use option, assuming that the utility farmers derived from one or another land use option within a particular choice set, let's say $\mathrm{C}$, which consists of all attributes related to this option. Thus, the functional form which assumes farmers utility function looks as follows:

$$
\mathrm{Uij}=\mathrm{V}(\mathrm{Zij}, \mathrm{Si})+\varepsilon \mathrm{i}
$$

Where for any of the i-farmers, a certain level of utility he or she derives is linked to any other land use options $\mathrm{j}$. Zdenotes the attributes of the land use options $j$, the farmer-i derives utility form. Further, the farmer's utility level associated with the choice of land use option $\mathrm{j}$ includes observable like a V-vector of attributes describing the goods which affect the farmers preferences complemented by Ssocio-economic characteristics of the farmers, and stochastic components respectively.

All other unobservable factors having impact on the decision process of farmers are captured by stochastic component e. Conventionally, it is assumed that the farmers will choose an option which gives the greatest utility. Thus, following [5], the probability that a farmer - i chooses alternative $-\mathrm{j}$, among other alternatives within the given choice set $\mathrm{C}$ is formulated as follows:

$$
\operatorname{Pi}(\mathrm{j})=\operatorname{Pr}\left(\mathrm{Uij} \geq \operatorname{Uim},{ }_{\mathrm{m}} \boldsymbol{E}_{\mathrm{Ci}, \mathrm{j} \neq \mathrm{m})}\right.
$$

Since the utility of each alternative here are divided into two, namely observable and error term components, we rewrite the equation (2) to include aforementioned components:

$$
\begin{aligned}
& \operatorname{Pi}(\mathrm{j})=\operatorname{Pr}(\mathrm{V}(\mathrm{Zij}, \mathrm{Si})+\varepsilon i \mathrm{j} \geq \mathrm{V}(\mathrm{Zim}, \mathrm{Si})+\varepsilon i m, \\
& \forall_{\mathrm{m}} \in_{\mathrm{Ci}, \mathrm{j} \neq \mathrm{m})}
\end{aligned}
$$

Further, if the dependant variables take three or more values, a multinomial logit model is employed. Encompassed by other probabilistic models, multinomial logit model implies that the condition of independently and identically distributed stochastic component or in other terms called error terms, must come across in line with a Gumbel distribution, namely IIA property [6].

Assuming equation (1) $\forall_{\mathrm{m}} \quad \in_{\mathrm{Ci}}$, for the computational purposes the multinomial logit or conditional logit, results in a conditional indirect utility function taking a linear functional form and can be written as [7] :

$$
\begin{aligned}
& \mathrm{Vij}=\mu(\beta+\beta 1 \mathrm{Z} 1+\beta 2 \mathrm{Z} 2+\ldots .+\beta \mathrm{nZn}+\beta \mathrm{aS} 1+ \\
& \beta \mathrm{bS} 2+\ldots .+\beta \mathrm{mSj})
\end{aligned}
$$

Where $\beta$ denotes the ASC (Alternative Specific Constant), representing the utility of zero payment option and in this study, defined as a 'status quo'. The vector of attributes of the land use options are represented by coefficients $\beta 1$ to $\beta \mathrm{n}$, and $\beta \mathrm{a}$ to $\beta \mathrm{m}$. S1 to $\mathrm{Sj}$ stand for socio-economic characteristics of the farmers.

After parameter estimations are accomplished, a measure of economic value can be calculated for each land use options or attributes using the following equation:

$$
C S=\frac{\ln \Sigma_{k} \exp (v k i)-\ln \Sigma_{k} \exp (v k o)}{\alpha}
$$

Where CS is the compensating surplus welfare estimate,

$\alpha$ is the marginal utility of income, which represents the coefficient of monetary attribute in the choice experiment, Vki and Vko are indirect utility functions before and after the change under consideration. Following [8], the reduced form of equation (5), looks as follows:

$$
W=1-\left(\frac{\text { Battribute }}{\text { Bmoneytaryatribute }}\right)
$$

The ratios above represent a marginal implicit prices or in other words marginal rate of substitution between land use attributes and money.

\section{B. Attributes of Choice Experiment}

In this section will be discussed a list of attributes of Choice Experiment that were used in the survey. As previously explained, this study is to explore farmer's preferences toward bioenergy development over the existing condition or the current farming practices. There are at least three main categories to be involved in CE analysis of this study, considered as land use change drivers: environmental aspect, socio-economic aspect and monetary factor. Socio- 
economic aspect include: traditional agriculture, bioenergy development and payment mechanims. Environmental aspects would be the carbon payment mechanism if the proposed project to be implemented. Monetary factor include the amount of payment based on the opportunity costs. There are five attributes with 3-6 levels used in this study, as shown in Table 3,

A farm household survey was implemented, targeting three different groups of local and immigrant farmers in different local communities across the case study area. A total of 375 interviews will be carried out with the help of 8 trained interviewers. The choice experimental design was construceted as shown in Table 4 . The survey measured the current land use and farmer attitudes and preferences for alternative land uses, including biofuel production. Particular attention was paid to the opportunity costs of peatland conservation and the benefits of peatland restoration, and the institutional-economic conditions needed to be in place to encourage farmers to change or modify their current land use practices. A choice experiment is carried out following the methodology outlined in [9] and [10]. The economic value of avoided deforestation and peatland conservation is estimated using the data collected in the farm household survey.

TABLE III

THE CHOICE CARD

\begin{tabular}{|c|c|c|}
\hline No & Attribute & Level \\
\hline $\mathrm{H} 1$ & Contract Provider & $\begin{array}{l}\text { Baseline: no contract provider } \\
\text { a. Local government (Office of } \\
\text { Forrestry, Office of } \\
\text { Agriculture) } \\
\text { b. Private Company } \\
\text { c. International NGO }\end{array}$ \\
\hline $\mathrm{H} 2$ & $\begin{array}{l}\text { Contract length over } \\
\text { which they receive an } \\
\text { additional stable income } \\
\text { for their restoration } \\
\text { activities }\end{array}$ & $\begin{array}{l}\text { Baseline: no contract } \\
\text { a. } 5 \text { years } \\
\text { b. } 10 \text { years } \\
\text { c. } 15 \text { years }\end{array}$ \\
\hline $\mathrm{H} 3$ & $\begin{array}{l}\text { Land restoration activity: } \\
\text { increase in water table }\end{array}$ & $\begin{array}{l}\text { Baseline: no increase } \\
\text { a. } 0-10 \mathrm{~cm} \\
\text { b. } 10-20 \mathrm{~cm} \\
\text { c. } 20-40 \mathrm{~cm}\end{array}$ \\
\hline $\mathrm{H} 4$ & Reforestation activity & $\begin{array}{l}\text { Baseline: no reforestation } \\
\text { a. planting of trees for carbon } \\
\text { sequestration on } 25 \% \text { of the land, } \\
\text { remainder for agriculture and/or } \\
\text { bioenergy } \\
\text { b. planting of trees for carbon } \\
\text { sequestration on } 50 \% \text { of the land, } \\
\text { remainder for agriculture and/or } \\
\text { bioenergy } \\
\text { b. planting of trees for carbon } \\
\text { sequestration on } 75 \% \text { of the land, } \\
\text { remainder for agriculture and/or } \\
\text { bioenergy }\end{array}$ \\
\hline $\mathrm{H} 5$ & $\begin{array}{l}\text { Additional compensation } \\
\text { payment }\end{array}$ & $\begin{array}{l}\text { Baseline: no compensation } \\
\text { a. Rp. } 10,000,000 \text { per ha/year } \\
\text { b. Rp. } 12,500,000 \text { per ha/year } \\
\text { c. Rp. } 15.000 .000 \text { per ha/year } \\
\text { Rp. } 30.000 .000,- \text { per ha } \\
\text { Rp. 30.000.000,- per ha } \\
\text {. Rp. } 30.000 .000,- \text { per ha }\end{array}$ \\
\hline
\end{tabular}

TABLE IV

CHOICE EXPERIMENTAL DESIGN

\begin{tabular}{|c|l|l|l|l|l|l|l|}
\hline $\begin{array}{c}\mathrm{N} \\
\mathrm{o}\end{array}$ & \multicolumn{1}{|c|}{ Attribute } & \multicolumn{5}{|c|}{ LEVEL } & \\
\hline 1 & $\begin{array}{l}\text { Contract } \\
\text { Provider }\end{array}$ & $\begin{array}{l}\text { Local } \\
\text { Gover } \\
\text { nment }\end{array}$ & $\begin{array}{l}\text { Private } \\
\text { Sector }\end{array}$ & $\begin{array}{l}\text { Intern } \\
\text { ational } \\
\text { NGO }\end{array}$ & & & \\
\hline 2 & $\begin{array}{l}\text { Contract length } \\
\text { (years) }\end{array}$ & 5 & 10 & 15 & & & \\
\hline 3 & $\begin{array}{l}\text { Water table } \\
\text { (cm) }\end{array}$ & $0-10$ & $10-20$ & $20-40$ & & & \\
\hline 4 & $\begin{array}{l}\text { Land for } \\
\text { restoration (\%) }\end{array}$ & $25 \%$ & $50 \%$ & $75 \%$ & & 20 & 22.5 \\
\hline 5 & $\begin{array}{l}\text { Compensation } \\
\text { (million } \\
\text { Rp/ha/year) }\end{array}$ & 10 & 12.5 & 15 & 17.5 & 20 & \\
\hline
\end{tabular}

\section{THE RESULT}

To determine whether the model without interaction used to explain farmers' preferences is valid and fit with the actual condition, validity test was implemented, namely Likelihood Ratiotest (LR). Table 5 shows the output of the validity test result using STATA.

TABLE V

OUTPUT OF MODEL Without INTERACTION

\begin{tabular}{|llll|}
\hline Iteration 0: $\log$ likelihood $=-1306.7239$ & & \\
Iteration 1: $\log$ likelihood $=-1306.7229$ & & \\
Iteration 2: $\log$ likelihood $=-1306.7229$ & & \\
& & & \\
Conditional (fixed-effects) logistic regression & Number of obs & $=$ & 2700 \\
& LR chi2(12) & $=$ & 790.60 \\
& Prob > chi2 & $=$ & 0.0000 \\
& Pseudo R2 & $=$ & 0.2323 \\
Log likelihood $=-1306.7229$ & & &
\end{tabular}

The output shows that the value of LR chi2 (12) is 790.60 with probability value $(0,000)$, which is less than 0.05 , meaning $\mathrm{H} 0$ is rejected. The test proved that the $\mathrm{CE}$ model applied in this study is valid. Pseudo R2 value of 0.2323 illustrates the value for $\mathrm{R} 2$ for non-linear model. This value of pseudo R2 is good enough in this model of without interaction.

To estimate the validity of the model with interaction on the respondents or farmers' preferences, this study also applied Likelihood Ratiotest (LR). The result of the STATA output for the validiy test is shown in Table 6.

TABLE VI.

OUTPUT OF MODEL WITH INTERACTION

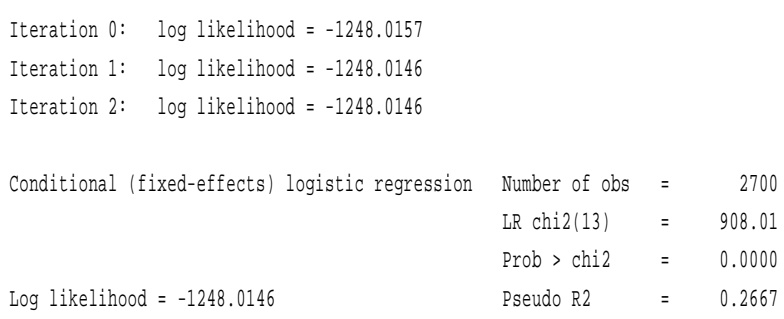


The output shows that the value of LR chi2 (13) at 908.01 with probability value $(0,000)$, which is less than alpha of $5 \%$ suggesting to reject $\mathrm{H} 0$. This proved that the model with interaction is valid in this study. Pseudo R2 value of 0.2667 represents the value of R2 for non-linear shape model, suggesting that pseudo R2 values are valid for the model with interaction.

Table 7 shows the hypothesis test on farmers' preferences using Wald Test. Results in Table 7 shows the regression coefficients and p-value in both models without interaction and the interaction with test factors that influence preferences. To determine whether the effect of a variable is statistically significant or not it is necessary to apply Wald Test. Using this method, the null hypothesis is $\beta \mathrm{i}=0$ (there is no significant effect), while the alternative hypothesis is $\beta \mathbf{i}$ $\neq 0$ (there is significant effect). The effect on the utility function can be seen from the positive and negative values of the regression coefficients. If positive means increasing utility function, otherwise, if negative means reducing the utility function.

The interpretation of the effect of each variable on respondent preferences will be detailed in this section. The effect of each variable to respondent preferences are as follows: the effect of Contract Provider, i.e., 1) Private Company, (2) international NGO, and (3) local Government, has a significant effect on consumer preferences. The Wald test to determine the effect of Contract Provider resulted in a coefficient of 0,105 with probability value of 0.093 . This coefficient is less than 0.10 suggesting to reject $\mathrm{H} 0$ which means that Contract Provider has significant effect on farmers' preferences. For models with interaction resulted in a coefficient of 0,118 with a value probability (0.066), which is less than $10 \%$ suggesting to reject $\mathrm{H} 0$. This means that Contract Provider has significant effect on consumer preferences.

The effect of c_length (Length of contract) resulted in a coefficient of -0.119 with probability value of 0.000 , which is less than $10 \%$ suggesting to reject $\mathrm{H} 0$. This means that cLength has significant influence on farmers' preferences. For models with interaction resulted in a coefficient of 0.121 with probability value $(0.000)$, which is less than $10 \%$, meaning to reject $\mathrm{H} 0$, which represent that c-Length factor provide significant effect on consumer preferences. Similar condition also existed on water table variable. Wald test resulted in a coefficient of 0.058 with probability value of 0.000 , which is less than $10 \%$. This suggested to reject $\mathrm{H} 0$ meaning that the water table provides significant effect on farmers' preferences. For models with interaction resulted in a coefficient of 0.298 with probability value (0.000), which is less than $10 \%$ suggesting to reject $\mathrm{H} 0$. This means that the water table has significant influence on consumer preferences.

The effect of land set-aside (\%) resulted in a coefficient of -0.008 with probability value of 0.000 , which is less than $10 \%$. This suggested rejecting $\mathrm{H} 0$, which means that land set-aside has significant influences on farmers' preferences. For models with interaction coefficient of -0.017 with probability value $(0.000)$ where the value of alpha probability is less than $10 \%$ reject $\mathrm{H} 0$ means land set-aside has significant influence on consumer preferences
TABLE VII.

HyPothesis Test On Respondents' PREFERENCES (WALD TeST)

\begin{tabular}{|c|c|c|c|c|}
\hline \multirow{2}{*}{ Variable } & \multicolumn{2}{|c|}{ Without Interaction } & \multicolumn{2}{|c|}{ With Interaction } \\
\hline & Coef. & $\mathrm{P}>|\mathrm{z}|$ & Coef. & $\mathrm{P}>|\mathrm{z}|$ \\
\hline ASC & $-7,481$ & 0,240 & $-10,073$ & 0,119 \\
\hline $\begin{array}{l}\text { Contract Provider } \\
\text { (prov) }\end{array}$ & 0,105 & $0,093^{*}$ & 0,118 & $0,066^{*}$ \\
\hline $\begin{array}{l}\text { Contract length } \\
\text { (c_lenght) }\end{array}$ & $-0,119$ & $0,000^{* *}$ & $-0,121$ & $0,000 * *$ \\
\hline Water table & 0,058 & $0,000^{* *}$ & 0,298 & 0,000 ** \\
\hline Land set-aside & $-0,008$ & $0,002^{* *}$ & $-0,017$ & $0,000^{* * *}$ \\
\hline compensation & 0,077 & $0,000^{* * *}$ & 0,057 & $0,000^{* *}$ \\
\hline distance & $-0,029$ & 0,120 & & \\
\hline Age & $-0,038$ & $0,001 * *$ & & \\
\hline $\mathrm{Age}^{2}$ & 0,000 & $0,002 * *$ & & \\
\hline Sex & 0,301 & 0,522 & & \\
\hline Famsize & 0,067 & 0,117 & & \\
\hline Income & 0,000 & $0,097^{*}$ & & \\
\hline c_length*distance & & & 0,055 & $0,000 * *$ \\
\hline c_length*famsize & & & 0,064 & $0,004 * *$ \\
\hline water*distance & & & $-0,015$ & $0,000 * *$ \\
\hline water*famsize & & & $-0,013$ & $0,010^{\text {** }}$ \\
\hline water*income & & & $\begin{array}{r}-2,90 \mathrm{E}- \\
09 \\
\end{array}$ & $0,000 * *$ \\
\hline Land*income & & & $5,19 \mathrm{E}-10$ & 0,018 ** \\
\hline $\begin{array}{l}\text { Compensation * } \\
\text { income }\end{array}$ & & & $1,33 \mathrm{e}-0,9$ & 0,036 ** \\
\hline Prov*age & & & 0,000 & $0,001 * *$ \\
\hline Prov*famsize & & & 0,007 & $0,000 * *$ \\
\hline Prov*income & & & $\begin{array}{r}-4,51 \mathrm{E}- \\
10 \\
\end{array}$ & 0,000 ** \\
\hline
\end{tabular}

The Wald test to determine the effect of Compensation resulted in a coefficient of 0.077 with probability value of 0.000 , which is less than 0.10 suggesting to reject H0. This means that Compensation payment has significant effect on consumer preferences. For models with interaction resulted in coefficient of 0.057 with probability value $(0.000)$ while the value of alpha probability is less than $10 \%$ suggesting to reject $\mathrm{H} 0$. This means that land set-aside has significant influence on farmers' preferences.

The effect of distance variable do not has significant effect on farmers' preferences. This can be seen from the coefficient obtained from the Wald test is -0.029 with probability value of 0.120 , which greater than 0.10 suggesting to accept $\mathrm{H} 0$. It means the distance variable has no significant effect on the farmers' preferences. However, the effect of age provides significant effect on farmers' preferences. The Wald test resulted in a coefficient of 0.038 with probability value $(0.001)$ where the value of alpha less than $10 \%$ reject $\mathrm{H} 0$ does it mean age was significantly effected by farmers' preferences. Similar condition for Age2 variable, in which the Wald test has resulted a coefficient of 0.0003 with probability value of 
0.002 . Since the coefficient is less than $10 \%$, it suggested rejecting $\mathrm{H} 0$, which means Age2 variable has significant effect on farmers' preferences. The wald test for the sex variable resulted in a coefficient of 0.301 with probability value of 0.522 , which is greater than 0.10 , suggesting to accept H0. This means that sex variable has no significant effect on consumer preferences.

The wald test for famsize variable resulted in a coefficient of 0.067 with probability value of 0.117 , which is greater than alpha 0.10 , suggesting to accept H0. This means that the family size (famsize) has no significant effect on farmers' preferences. The validity test is also implemented for income variable. The Wald test resulted in a coefficient of $-8.56 \mathrm{E}-09$ with probability value of 0.097 , which is less than 0.10 suggesting to reject $\mathrm{H} 0$. Variable of income have significant effect on farmers' preferences.

\section{CONCLUSIONS}

A choice experiment methodology was applied to examine several factors that influence the farmers preferences on the compensation granted as a result of bioenergy project. This study applied principles of discrete choice experiment, that is the alternative chosen by the respondents and the probability of each alternative selected by respondent is estimated based on the utility function of the variables that influence people to choose. The statitical data processing has been performed with STATA. Model without interactions is estimated by performing Wald test at alpha of 0.10 resulted in variables that provide significant effect on farmers preferences, these are: contract provider, length of contract (c_length), water table, land set-aside, compensation, age of respondent, age 2 , and income, whereas variables that do not affect significantly on farmer's choice are: distance, family size (famsize) and sex. The value of LR chi2 (12) is 790.60 with probability value of 0,000 , which is less than 0.05 suggesting to reject $\mathrm{H} 0$. This has proved that the model used in this study is valid. Pseudo R2 value of 0.2323 in this study which illustrates the value of $\mathrm{R} 2$ for the shape of non-linear model, indicating that pseudo R2 value is good enough in the model.

Results of the model with interaction resulted in LR chi2 value (12) at 908.01 with probability value $(0,000)$. This value is less than alpha of $5 \%$ suggesting to reject $\mathrm{H} 0$ and proved that the model is valid for this research. Pseudo R2 value in the study is 0667 which illustrates the value of R2 for the shape of non-linear model, Pseudo R2 value is good enough in the model. The wald test on alpha $10 \%$ shows variables that has significant effect to farmer preferences are: Contract Provider (prov), length of contract (c_length), water table, land set-aside, compensation. Variable interactions which were significant are: Contract length (c_length) with distance, c_length with family size (famsize), water table with distance, water table with famsize, water table with income, land with income, compensation with income, provider (prov) with age, prov with famsize, prov with income.

Results of the model with interaction produces a better model than the model without interaction, indicating that respondents in determining the choice of not only influenced by a single factor but interacted with other factors. Water table is the most influencing factor on farmers' preferences as well as interactions with income, family size and distance. This indicates that preferences of respondents or farm household do not only depend on water table but also consider other variables such as income, family size and distance.

\section{ACKNOWLEDGMENT}

We would like to express our sincere thanks to the Royal Netherlands Academy of Arts and Sciences for financially supporting this research under the Scientific Programme Indonesia - Netherlands (SPIN).

\section{REFERENCES}

[1] Priess, J. A., G. H. J. d. Koning, et al. "Assessment of interactions between land use change and carbon and nutrient fluxes in Ecuador." Agriculture, Ecosystems and Environment, vol 85: pp 269-279, 2001.

[2] Merino-Castello, A. (2003) Eliciting Consumer Preferences Using Stated Preference Discrete Choice Models: Contingent Rank-ing Versus Choice Experiments Volume, DOI: http://www.econ.upf.edu/docs/papers/downloads/ 705.pdf.

[3] Henser, D. A., Rose, J.M., \& Greene, W.H., Applied Choice Analysis. Cambridge University Press, 2005.

[4] Rolfe, J. C. and J. W. Bennett, Testing for Framing Effects in Environmental Choice Modeling, The Universityof New South Wales, Sydney - Australia, 2010.

[5] Ben-Akiva, M. and S. R. Lehrman, Discrete Choice Analysis: Theory and Application to Travel Demand, M. A.: MIT Press, 1985.

[6] Luce, D., Individual Choice Behaviour. New York NY: John Wiley. 1985.

[7] McFadden, D. "Conditional logit analysis of qualitative choice behaviour", . Frontiers in Econometrics, P. Zarembka, Academic Press: New York: pp 105-142. 1973.

[8] Hanemann, W. M, "Valuing the Environment through Contingent Valuation", Journal of Economic Perspectives." Vol 8(4), pp19-43, 1984.

[9] VanBeukering, P., M. Schaafsma, et al. (2008). The Economic Value of Peatland Resources Within The Central Kalimantan Peatland Project in Indonesia Perceptions of Local Communities, IVM Report E-08/05, Vrije Universiteit Amsterdam, The Netherlands, 2008.

[10] Tesfaye, A. and R. Brouwer, "Testing participation constraints in contract design for sustainable soil conservation in Ethiopia.", Ecological Economics, vol 73, 2012 